\title{
Grammatical Accuracy using Teacher's Written Corrective Feedback
}

\author{
Solfiyatuzzahro', Asih Santihastuti², Erfan³ \\ English Study Program, Language and Art Department \\ University of Jember \\ Email: solfiyatuzo6@gmail.com
}

\begin{abstract}
The purpose of this research was to improve grammatical accuracy on writing descriptive text by using Teacher's Written Corrective Feedback and to know their perceptions toward the application of the technique in teaching writing. This research design was a classroom action research that was conducted collaboratively with the English teacher. The result of the data analysis revealed that the application of Teacher's Written Corrective Feedback could improve the tenth grade students' grammatical accuracy. The improvement of students' grammatical accuracy could be seen from the percentage of students who got score $\geq 71$ increased from $72 \%$ in the first cycle to $78 \%$ in the second cycle. The students' accuracy could be seen from the improvement of grammar accuracy in each grammatical aspect. The result showed that students' grammar score highly improved in present tense and noun/pronoun aspects. Teacher's Written Corrective Feedback and the procedure used such as additional explanation from teacher and revision process could help the students improve their grammatical accuracy in writing. Besides, students thought Teacher's Written Corrective Feedback had favorable impact which it was beneficial and meaningful for them to overcome their difficulties in writing and to make them aware of their errors.
\end{abstract}

Keywords: Written Corrective Feedback, Classroom Action Research, Grammatical Accuracy, English Foreign Laguage, Descriptive Texts

\section{https://ojs.unm.ac.id/eralingua}

\section{INTRODUCTION}

Writing is seen as a complex and difficult skill to learn which requires students to master not only the linguistics aspect but also the cognitive one. Richard and Renandya (2002) said that writing is the most difficult skill to master for the English language learners. Basyal (2009) added that writing is a complex task because it requires a variety of skills such as mastering vocabulary, grammar, and organization of the text. Besides, Aliakbari (2009) said that writing requires an accurate knowledge of grammar system. The emphasis on accuracy is justified to the production of structurally correct and to prevent inaccuracy that may result of structurally erroneous sentences. Furthermore, Gottsäter (2018) stated that a lack of knowledge of grammar increases the risk of communication breakdown. 
Based on the preliminary study done by interviewing some English teachers, the researcher found out that the students' major problem in writing was they still did not know how to structure their writing in accurately. The teacher said that students were better in other components of writing such as mechanics and organization. However, they failed to recognize and use the appropriate grammar in writing. They were confused either using present tense or past tense. Teacher commonly gave feedback on the students' work by using one or two students' work as the example for the whole class. Then he wrote the work on the white board to be corrected together with the students. By knowing their friends' mistakes, other students were hoped to be able to revise their own errors. It could be said that teacher had tried to give students feedback on students' work. Nevertheless, the feedback given was less effective because students still felt confused. There are some errors that are untreatable to self-correction such as sentence structure and word choice (Ellis, 2009). When the case is on grammar, students might face situation which they could not correct the errors by themselves as the teacher did it only to some students' work instead of individual feedback. In other words, students' might not be able to revise their own work by observing their friends' work only. It might become the reason of the tenth MIPA 3 still made most errors on their grammar that led to the low mean score in writing. The result indicated that the percentage of the students who achieved the standard score (71) was only $67 \%$ students or 24 students of 36 students.

Regarding the problem found in the preliminary study, providing the effective feedback on the students' errors was very crucial for students' writing improvement. By giving individual correction, students knew their mistakes in order to fix their next writings to be better. Further, the demand for corrective feedback cannot be disregarded. Ferris (1999) had showed L2 student writers want, expect, and value teacher feedback on their written errors. The main reason might be that their subject teachers require accuracy in students' L2 writing in their writing classes.

Hendrickson suggested that some errors that obstruct communication or those that students made frequently might have higher priorities for correction than others (Ekinci, 2017). Teacher should decide which errors would be corrected to make the best use of providing written feedback to the students. In this research, the researcher gave written corrective feedback on grammar because students made frequently errors on grammar when they constructed text. Grammar was emphasis more than other errors to make the students concentrated more on grammar first before the other components of writing.

There has been a growing interest in applying teacher's feedback on teaching and learning writing process. Using different research designs and different participants, this issue has been investigated by a number of researchers 
(e.g Sheen, 2007; Shirazy and Shekarabi, 2014; Hasan, 2014; Hosseiny, 2014, Saadi and Saadat, 2015; Khanlarzadeh and Nemati, 2016. Ekinci, 2017). Based on the research findings, it convincingly proved that teacher's feedback could improve students' grammatical accuracy and writing skill. Moreover, there were also some supports of using direct corrective feedback as the effective technique to improve students' grammatical accuracy.

Each study had different characteristic with this present study. First, most of the previous researches used experimental research. Two researches implemented classroom action research with the implementation of error codes/indirect and conference/oral feedback. This research applied classroom action research with the implementation of direct written feedback. Second, most of the previous studies were concerned in the cognitive aspects, only a few studied on the affective aspects. Next, the grammar aspects were addressed between the previous research and this research. The last, the participant of those studies ranging from preparatory school students, elementary EFL learners, junior high school students up to University students, and also L2 students. However, this reseach involved the tenth grade of MIPA 3 of SMAN Rambipuji. Considering the issue above, the researcher is interested to find out if teacher corrective feedback could help students improve their grammatical accuracy on writing descriptive texts and how are their perceptions toward the application of teacher's written corrective feedback.

\section{LITERATURE REVIEW}

\section{Formative Assessment and Teacher's Written Corrective Feedback}

According to Tuttle (cited in Gottsäter, 2018) stated that formative assessment is something which teachers use in order to find out how much a student has achieved so far, and what the student could do in order to improve their knowledge. Tuttle further explained that one way to engage in formative assessment is through written corrective feedback. However, for the written corrective feedback to be formative, it has to be done in a certain way which is formative when teacher presents students with a way to increase their knowledge that could be in the form of informing them of how a specific grammatical structure is supposed to be constructed. However, only informing students what they did wrong is not formative. It is the step after it which might qualify the corrective feedback as formative.

According to Mobini \& Khisravi (2016), written corrective feedback is a teacher's input to a writer's composition in the form of information to be used for revision. According to Ellis (2009), direct corrective feedback is the way to inform students about the location and the correct forms of the errors. He also generally illustrates direct correction on students' works. It takes a number of different ways; crossing out an unnecessary word, morpheme, inserting a missing word or 
morpheme, and writing the correct form above or near to the erroneous form. Teacher, then, provides the students with correct form.

In the context of this research, teacher's written corrective was given in the form of direct corrective feedback. Ellis (2009) states that direct corrective feedback is the way to inform students about the location and the correct forms of the errors. He also generally illustrates direct correction on students' works. It takes a number of different ways; crossing out an unnecessary word, morpheme, inserting a missing word or morpheme, and writing the correct form above or near to the erroneous form. Teacher, then, provides the students with correct form.

Different studies proposed some procedures in implementing direct feedback. Sheen (2007) used 9 steps in his procedure of implementing written feedback: 1) giving the students the story with an empty writing sheet attached to it; 2) asking students to read; 3) explaining the key words and moral value ; 4) asking the students to tear off the story part; 5) reading the story aloud. It is done by the teacher. 6) asking students to rewrite the story.; 7) collecting the students' written work ; 8) correcting the students' work; 9) asking the students to check over their written work carefully for 5 minutes. In this procedure the students were only asked to study the corrections rather than to redraft their written narratives. The result showed that students have positive effect after being given feedback.

Another procedure was proposed by Nemati and Khanlarzadeh (2016) examined the effectiveness of written corrective feedback in the improvement of EFL learners' grammatical accuracy. There were 5 steps as follows: 1 ) providing students with an acceptable writing sample; 2) asking the students to produce writing assignment; 3) asking the student to submit it; 4) giving back the students' scored drafts in the next session; 4) giving students enough time to consult during in-class revision; 5) asking the students to revise it. The result revealed that the students who got feedback (experimental group) performed much better than those in control group.

Thus, this research adapted the procedure of giving direct feedback by adapting from those two previous researches, Sheen (2007) and Nemati and Khanlarzadeh (2016)

\section{The Advantages of Teacher's Written Corrective Feedback Technique}

According to Ellis (2009), teacher's direct corrective feedback has some advantages. They are as follow:

1. Direct corrective feedback is beneficial in providing learners with explicit guidance about how to correct their errors.

2. Direct corrective feedback can be used by the teacher to help the students' difficulties such as using appropriate, accurate and complete responses, correct spellings and punctuation and grammatical accuracy in writing activity.

3. Direct corrective feedback may be appropriate for beginner students or in situation when errors are not amenable to self-correction such as sentence structure, and when teacher wants to direct students' attention to error patterns that require students correct them

According to, Bitchner and Knock (2009), direct corrective feedback reduces the type of confusion that the language learners may experience and it provides 
language learners with information to help them resolve more complex errors. Furthermore, according to (Sheen, 2007), direct corrective feedback can be effective in promoting acquisition of specific grammatical features.

\section{The Steps of giving Teacher's Written Corrective Feedback in Teaching Writing}

1. Providing students with passages as acceptable writing sample.

2. Asking the students to write a draft of a descriptive text based on the topic given. The draft should consist of the title, the generic structure and the language features of descriptive text.

3. Collecting the students' draft to be corrected at home.

4. Giving written corrective feedback in the form of direct corrective feedback by crossing out and circling the errors and then giving the correct form explicitly on the students' errors. The focus of the corrective feedback was the language features covering tenses, conjunction, adjective, and noun/pronoun.

5. Giving back the draft that had been given the feedback to the students in the next session. It was given after the teacher finished correcting the draft.

6. Asking the students to look at the corrections in their first draft carefully.

7. Asking the students to ask question about what they did not understand from the feedback. It was conducted during the in-class writing revision.

8. Giving enough time to discuss the students' errors that the students make in writing with the whole class. This additional oral explanation was aimed to give clearer explanation about the students' difficulties.

\section{RESEARCH METHOD}

This research applied classroom action research because the purpose of the researcher was to solve the student's difficulties in writing descriptive text and to improve the student's grammatical accuracy by using Teacher's Written Corrective Feedback. Furthermore, the cycle model of an action research was proposed by Lodico et al. (2010) consisted of four steps: planning, implementing, observing and reflection. Those four main steps were preceded by reconnaissance (preliminary study).

The research was conducted at SMAN Rambipuji. There were some reasons of choosing SMAN Rambipuji. First, the school uses Curriculum 2013. Second, there were students who got low score that was under the minimum standard score in writing test based on the result of interview with the English teacher in SMAN Rambipuji. Third, the headmaster of SMAN Rambipuji agreed and gave the permission to the researcher to conduct this research at the school. Moreover, the researcher had experienced to teach at SMAN Rambipuji.

The subjects of the research were the tenth grade students of SMAN Rambipuji. The class in the tenth grade that was chosen as the research participant was the tenth MIPA 3 grade students of SMAN Rambipuji, there were 36 students. They had problems with their writing achievement especially in grammar aspects when they wrote a descriptive text. The reason of choosing the tenth MIPA 3 grade students was based on the suggestion of the teacher that most of the students of class tenth MIPA 3 had difficulties in writing skill especially in grammar aspects.

Test was used to measure students' abilities in certain fields of knowledge. The researcher applied achievement test in this classroom action research to 
measure the tenth grade students' grammatical accuracy on writing descriptive texts. The writing test in this research referred to writing a descriptive text. The form of the test was a writing test consisting of approximately 150 words based on the topic given. The topic was tourism or historical places in Jember. The students were required to compose a descriptive text based on the topic given completed with correct generic structure and language features of descriptive text. The writing test was lasted for 45 minutes. The writing test was conducted to obtain the score of students' grammatical accuracy.

This research used questionnaire as a method to collect data about students' feelings or perceptions of using teacher's written corrective feedback. Students' questionnaire about their perception on writing skill was adapted from Ekinci (2017) (see table 1). Likert Scale was used in questionnaire consisted of six questions. The range was from number 4 shows the highest frequency (strongly agree) up to 1 shows the lowest one (strongly disagree).

Table 1. The Questionnaire of Students' Perceptions toward the Application of Teacher's Written Corrective Feedback

\begin{tabular}{lll}
$\begin{array}{l}\text { What do you think about these } \\
\text { sentences about writing skill? }\end{array}$ & $\begin{array}{l}\text { Strongly Agree } \\
\text { Agree }\end{array}$ & Disagree $\begin{array}{l}\text { Strongly } \\
\text { disagree }\end{array}$ \\
\hline
\end{tabular}

1. Writing is a vital part of learning English.

2. I learn more from the correction provided by the teacher.

3. I learn from my own errors.

4. I think error correction is easy to learn.

5. I think using error correction in writing helps me to focus more on my errors.

6. When I get back my paper with correction provided by the teacher, I check them to avoid doing the same errors again.

Data analysis method was used to analyze the data gained in the research. To score each paper related student's grammatical accuracy, the researcher used the formula by Sheen (2007:266). Each student's work was scored according to Sheen's formula four times by the researcher that were respectively scoring tense, adjective, noun/ pronoun, and conjunction. Below is the formula.

Score:

$$
\frac{n \text { correct suppliance in context }}{n \text { obligatory contexts }+n \text { suppliance in non }- \text { obligatory context }} \times 100
$$

Notes:

Obligatory context= the correct use of the target use. 
Non-obligatory context $=$ in appropriate of the target use.

(Sheen, 2007:266)

First, the correct use in obligatory context was scored. The score became the numerator of the ratio. The denominator was the sum number of obligatory contexts and the number of non-obligatory contexts. After scoring each student's work, the score was analyzed using descriptive statistics by calculating the number of students who have achieved 71 and below 71. The target of success criteria was $71 \%$ of the students achieving the minimum score which was at least 71 or more in the test. Then, the scores of students' test in cycle 1 were compared to students' test in cycle 2. This aim was to know whether or not there was the improvement of scores made in the first and second cycles.

\section{RESULT AND DISCUSSION}

After the actions were implemented, two problems which were the central of this study were answered. The following sub-chapters deal with the results.

How Can Teacher's Written Corrective Feedback Improve the Students' Grammatical Accuracy in Writing Descriptive Texts? The average result of the improvement of the students' grammatical accuracy was presented in table 1.

Table 2. The Improvement of Students' Grammatical Accuracy

\begin{tabular}{cccccccc}
\hline \multirow{2}{*}{ No. } & \multirow{2}{*}{ Cycle } & \multicolumn{3}{c}{ Grammatical Aspects } & \multicolumn{2}{c}{ Criteria of Success } \\
\cline { 3 - 8 } & T/V & N/P & ADJ & CONJ & Achieved & Not Achieved \\
\hline 1. & Pre-Cycle & 43 & 79.3 & 87.5 & 56 & $33 \%$ & $67 \%$ \\
\hline 2. & Cycle 1 & 45.3 & 84.5 & 91.6 & 94 & $72 \%$ & $28 \%$ \\
\hline 3. & Cycle 2 & 54.2 & 91.1 & 94.5 & 93.6 & $78 \%$ & $22 \%$ \\
\hline
\end{tabular}

Based on table 2, the action in Cycle 1 had been successful because the percentage of the students who got score $\geq 71$ in the writing test was $72 \%$ or 26 of 36 students. After the application of Teacher's Written Corrective Feedback in Cycle 1, the students gained more knowledge about the grammar target. The students also could compose a piece of writing in average of 80-161 words. Besides, some students were able to write more than the expected words in this research that was 150 words. The result of student's grammatical accuracy in writing test in Cycle 1 improved because the students had already got the feedback on their draft, they also got additional explanation from the researcher, and further they had an opportunity to practice the grammar in revision session

It was concluded that teaching writing descriptive text by using Teacher's Written Corrective Feedback gave positive response to the students writing. Direct corrective feedback and the procedures used, helped the students used more appropriate grammar on writing which consequently improved students' grammatical accuracy. Those activities were intertwined becoming one procedure to improve students' grammatical accuracy. 
The result of grammatical accuracy improvement in writing test could achieve the criteria of success in this research, if at least $71 \%$ of students got at least 71. It meant this Cycle was successful as there were $72 \%$ students got 71 . The researcher decided to continue Cycle 2 in order to encourage students' critical awareness about their mistakes and raise their self-review by conducting further action in Cycle 2. The researcher tried to encourage students' critical awareness about their mistakes and raise their self-review by modifying the procedure such follow.

1. The researcher gave further explanation about the most errors that the students made in Cycle 1. Meanwhile, in Cycle 2 the researcher did not include this step to stimulate students to learn the corrective feedback more independently and become more careful writers.

2. The students' writing achievement kept improving from $72 \%$ in Cycle 1 to $78 \%$ in Cycle 2. Therefore, this could convince us that the use of Teacher's Written Corrective Feedback could improve the students' grammatical accuracy test in Cycle 2 as well. Moreover, some students could also compose a piece of writing in average of more than 100 up to 187 words. It was more than Cycle 1 (161 words) and the expected words in the test which was 150 words. It indicated that students' creativity and their vocabularies were more increased than before. From the results, it could be concluded that the required target percentage in this research was fulfilled. The result in Cycle 2 showed the consistent results with Cycle 1. Therefore, the researcher stopped the action.

\section{How Are Students Perceptions about Teacher's Written Corrective Feedback?}

The result of students' questionnaire was that the first highest point was referred to item 1 (138 points) which indicated that students considered writing as essential part in learning English which was assumed to be the motivation for the students to learn writing in the class. The second was item 3 (131 points) indicated there was considerable chance that error correction made students also learnt something from their own errors. They were aware of their errors and they used them to avoid more errors. The third was item 6 (130 points) indicated that they check their errors to avoid doing the same errors again and again. The students' responses demonstrated that they began to show special care to their errors after the introduction of written corrective feedback. The fourth was item 2 (127 points) which meant that students felt that error correction is meaningful and worthwhile because they learnt much from the feedback. In other words, the students learnt more from the teacher's refinement. Further, it was item 5 (125 points) which indicated that written corrective feedback had favorable impact. From this result, students considered error correction given by the researcher was beneficial because it made them focus on their errors. The last was item 4 with the total score was 123 indicated that the students became familiar with written corrective feedback and they thought written corrective feedback was quite easy to comprehend.

The total score from the results analyzing questionnaire of 36 students $X$ MIPA 3 was 774. The calculation of students' score perception level is presented in the table below. 
Table 3. The Classification of Students' Score Perception Level

\begin{tabular}{ccc}
\hline Score level & Students' Questionnaire & Category \\
\hline 216 s $/ \mathrm{d} 378$ & & Strongly negative \\
\hline$>378$ up to $<540$ & & Negative \\
\hline$>540$ up to $<702$ & & Positive \\
\hline$>702$ & 774 & Strongly positive \\
\hline
\end{tabular}

Based on the results of score classification, students' score was classified as strongly positive or students gained positive perception. It meant that students had positive perceptions toward the written corrective feedback given by the teacher on their descriptive text writings

This action classroom action research was done to improve the students' grammatical accuracy and to know about students' perceptions toward the application of Teacher's Written Corrective Feedback at the tenth MIPA 3 students of SMAN Rambipuji. Teacher's Written Corrective Feedback was chosen to fulfil the objectives. Three aspects were seen to be effective to bring out significant improvement in enhancing students' grammatical accuracy level and students also gained positive perceptions toward teacher's written corrective feedback given.

The first aspect is "Direct Corrective Feedback" technique was fruitful for the students. The students committed fewer errors, and they learnt to write proper compositions. In this research, direct corrective feedback was given by crossing out and circling the errors forms and directly writing the correct form explicitly above the errors form. It could help students to instantly revise the errors. The researcher directed students' attention to the errors by crossing out or circling it. In addition, writing the complete and correct form near the errors form also became information for the students to overcome their difficulties and avoid making the same mistakes or even more complex errors. As it was stated by Bitchner and Knock (2009), direct corrective feedback provides language learners with information to help them resolve more complex errors and it reduces the type of confusion that the language learners may experience. The results of the present research showed the improvement of student's grammar score from each cycle. It was proven by looking at students' grammatical accuracy improvement in which students could reduce the errors they made in subsequent draft. Moreover, they were able to better recognize and use present tense, noun/pronoun, and conjunction more correctly and appropriately in the text. The improvement of students' grammatical accuracy was $6 \%$ from Cycle $1(72 \%)$ to Cycle 2 (78\%).

The second aspect is additional oral explanation that the researcher gave during the teaching learning process also played a great role in supporting the improvement of students' grammatical accuracy. It provided students with clearer explanation and understanding. Moreover, when this technique and teacher's additional oral explanation were given clearly and consistently, it would contribute to the students' long-term memory. Thus, it will work for acquisition. It is line with it Sermsook, et all (2017) said direct corrective feedback with teacher's clear explanation feedback helps to create students' better understanding of the 
targeted grammatical features. They conclude that this could reinforce long-term memory of those features.

The third aspect is revisions. It also had good influence for students' grammatical accuracy as it helped students to practice the structure. The revision was also intended to help them notice the objectives and benefits the type of the feedback and to employ the feedback to improve their writings. Moreover, the supports for implementing revision were relevant with the study supported this present study. Hosseiny (2012), students redraft after they received feedback on their errors in each session. They had enough opportunity to practice the structure, so they improved their skill in article system of English. Additionally, Nemati \& Khanlarzadeh (2016), the findings of his study revealed that provision of Written Corrective Feedback leads to error reduction when students are required to revise their previously written drafts, and that this error reduction is significantly higher than that with no feedback group. The improvement of the students' grammatical accuracy could be seen from the average score of the grammatical aspects. It could be known that the students' writing achievement kept improving from $72 \%$ in Cycle 1 to $78 \%$ in Cycle 2. Therefore, this convinces us that the application of Teacher's Written Corrective Feedback could improve the students' grammatical accuracy on writing descriptive text in Pre-Cycle, Cycle 1 Cycle 2 as well. It could be concluded that the required target percentage in this research was fulfilled.

Indeed, the implementation of Teacher's Written Corrective Feedback in this research could improve the students' grammatical accuracy and they also had positive perception toward the application of the feedback given. It was proven by looking at the results from Pre-Cycle to Cycle 1 and Cycle 2 which significantly improved. Moreover, the result of the score level of the questionnaire was categorized as strongly positive. It was highly recommended for teachers to use written corrective feedback in teaching and learning process, especially in teaching writing

\section{CONCLUSION}

Based on the result of the data analysis and discussion, there are two things that can be summarized that:

1. First, teacher's written corrective feedback and the procedure implemented can improve students' grammatical accuracy on students' descriptive text writing. The included procedures supported the success of written feedback such as; additional explanation session from the teacher and revision session after students got their paper back. The improvement of students'

2. Second, students also have positive perceptions toward the teacher's written corrective feedback given.

\section{REFERENCES}

Aliakbari, M., \& Toni, A. (2009). On the effects of error correction strategies on the grammatical accuracy of the Iranian English learners. Journal of Pan Pacific Association of Applied Linguistics. 13(1): pp99-112.

Basyal.(2009). A Model for Teaching Writing. Journal of NELTA, 14(1,2):pp281. 
Bitchner, J., \& Knoch, U. (2009). The realtive effectiveness of different types of direct written corrective feedback. System, 37(2), 322-329.

Ekinci, M. (2017). An Action Research: The Effect of Written Corrective Feedback and Error Codes in Improving Writing Skill. International Online Journal of Teachers in Collaboration. 1(1):pp31-46.

Ellis, R. (2008). A Typology of Written Corrective Fedback Types. ELT Journal. Oxford University Press.

Ellis, R.(2009). Corrective Feedback and Teacher Development. L2 Journal. 1(1):pp318

Ferris.(1999). Student reactions to teacher response in multiple-draft composition classrooms. TESOL Quarterly, 29: pp33- 53

Gottsäter. J (2018). Teacher feedback on Grammatical Errors: Stimulus for learning or confidence breaker?. Malmö University

Hasan, A. (2014). Improving the Seventh Grade Students' Active Participation and Their Simple Present Tense Achievement in Writing A Descriptive Paragraph by Giving Written Feedback at SMPN 02 BALUNG in the 2013/2014 Academic Year. Thesis. University of Jember.

Hosseiny, M. (2014). The Role of Direct and Indirect Written Corrective Feedback in Improving Iranian EFL Students' Writing Skill. Procedia - Social and Behavioral Sciences. 98:pp668-674.

Khanlarzadeh, M., \& Nemati, M. (2016). The effect of written corrective feedback on grammatical accuracy of EFL students: An improvement over previous unfocused designs. Iranian Journal of Language Teaching Research. 4(2):pp5568.

Lodico, M. S. (2010). Methods in Educational Research: From Theory to Practice (2nd Edition). San Fransisco: Josey-Bass.

Mobini, F., \& Khosravi, R. (2016). The Effect of Teachers' Written Corrective Feedback (WCF). Types on Intermediate EFL Learners' Writing Performance. Advances in Language and Literary Studies. 7(3)

Richard \& Reynanda. (2002). Methodology in Language Teaching:An Anthology of Current Practice. Cambridge University.

Saadi, K. \& Saadat, M. (2015). Iranian EFL Learners' Grammatical Knowledge: Effect of Direct and Metalinguistic Corrective Feedback. English Language Teaching Journal. 8(8)

Sermsook, et all. (2017). The Impact of Teacher Corrective Feedback on EFL Student Writers' Grammatical Improvement. Canadian Centre of Science and Education. 10(10)

Sheen, Y. (2007). The effect of focused written corrective feedback and language aptitude on ESL learners' acquisition of articles. TESOL Quarterly, 41, 225-283.

Shirazi, M., \& Shekarabi, Z. (2014). The role of written corrective feedback in enhancing the linguistic accuracy of Iranian Japanese learners' writing. Iranian Journal of Language Teaching Research. 2(1):ppg9-118 